\title{
Pentafluorophenylammonium Triflate: A Mild, Efficient and Reusable Catalyst for the Synthesis of 2-Arylbenzothiazole and 2-Arylbenzothiazoline Derivatives in a Green Chemical Approach
}

\author{
ARUP DATTA \\ Department of Chemistry, Shibpur Dinobundhoo Institution (College), 412/1, G. T. Road (South), \\ Howrah-711102, Shibpur, West Bengal, India. \\ *Corresponding Author E-mail: arupdattadb@gmail.com \\ http://dx.doi.org/10.13005/ojc/370112
}

(Received: October 20, 2020; Accepted: January 03, 2021)

\section{ABSTRACT}

In this work, one pot, simple and environmentally benign effective synthesis of 2-substituted benzothiazole and benzothiazoline derivatives are described in presence of PFPAT (pentafluorophenylammonium triflate) catalyst in water successfully. A series of benzothiazole derivative were synthesized by the reaction between 2-aminothiophenol and various aldehydes in good yields. Recyclability of the catalyst is observed for four times without loss of its activity in aqueous medium.

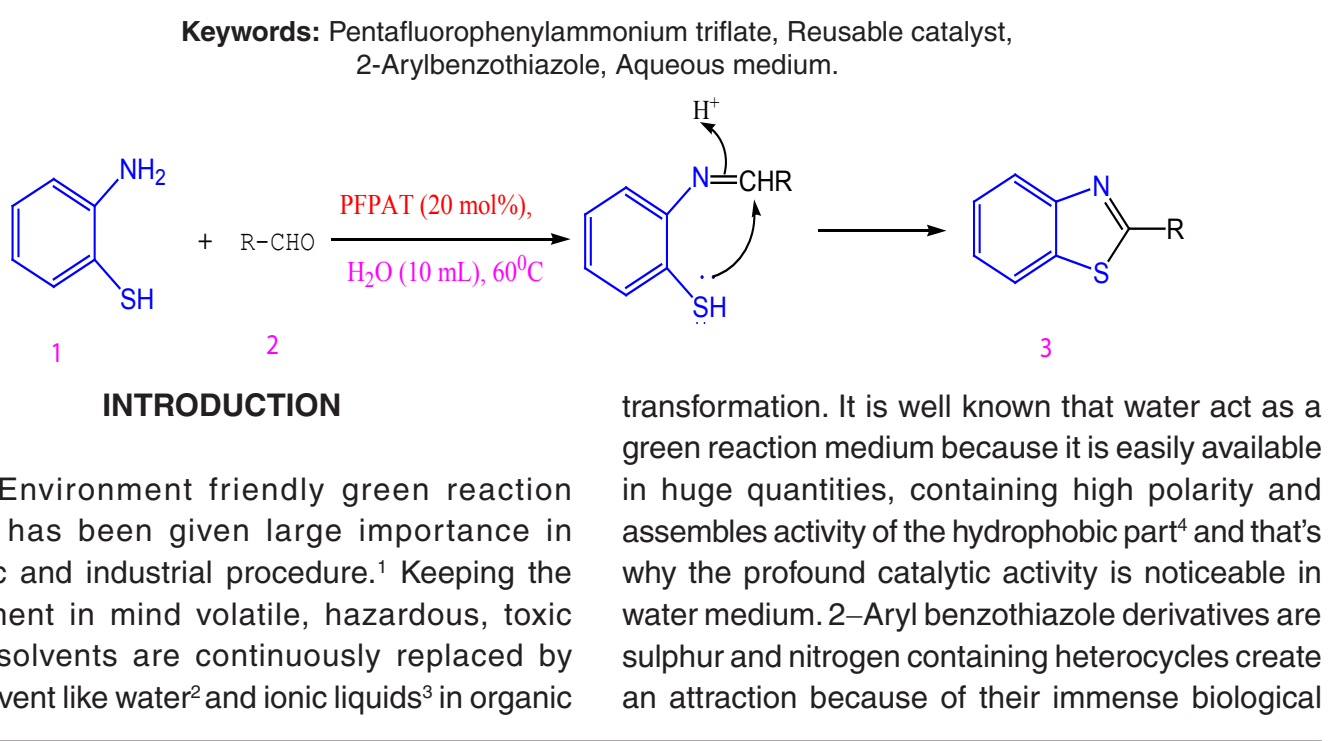

This is an Open Access article licensed under a Creative Commons license: Attribution 4.0 International (CC- BY). Published by Oriental Scientific Publishing Company @ 2018

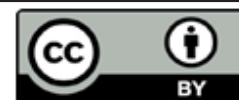


activity in a broad range. The benzothiazole nucleus possesses large pharmacological activity like anti-cancer, anti-viral, antitumor, anti-convulsant. ${ }^{5}$ Benzothiazolyl moiety act as a b-amyloid for the treatment of Alzheimer disease. The compounds like 2-(4'- dimethylaminophenyl)-benzothiazole and 2-(4'aminophenyl)-benzothiazole show inhibitory activity against human ovarian and renal cell lines. Derivative 2-(3', 4'-dimethoxyphenyl)-5-fluorobenzothiazole is used against breast, lung and colon cancer. Beside this, benzothiazole derivative is helpful for the treatment of anti-parasitics, anti-tuberculosis deseases. $^{6}$

There are numerous methods are available to design the benzothiazoyl moiety put condensation method is very common where o-aminothiophenols are reacted with acid derivatives ${ }^{7}$ like acid chloride, ${ }^{8}$ ester, ${ }^{9}$ nitriles. ${ }^{10}$ In the Second method, o-aminothiophenols are reacted with aldehydes using different catalyst in either different solvents or solvent less reaction medium to synthesize 2-arylbenzothiazole derivatives through condensation process. Catalyst like CAN, ${ }^{11}$ [Pmlm] $\mathrm{Br},{ }^{12} \mathrm{MnO}_{2} / \mathrm{SiO}_{2},{ }^{13} \mathrm{Sc}(\mathrm{OTf})_{3} / \mathrm{H}_{2} \mathrm{O}_{2},{ }^{14} \mathrm{H}_{3} \mathrm{PW}_{12} \mathrm{O}_{40} /$ $\mathrm{Zr}\left(\mathrm{HPO}_{4}\right)_{2}{ }^{15}, p$-TsOH,${ }^{16}$ and bakers' yeast, ${ }^{17}$ were used to develop the benzothiazole and some benzothiazoline derivatives. ${ }^{18}$ Reaction between o-aminothiophenol and aromatic aldehydes in microwave irradiation through direct method was also documented. ${ }^{19}$ Some catalyst such as $\mathrm{CBr}_{4}$, tin-modified monoammonium phosphate fertilizer, acacia concinna bio-catalyst and riboflavin catalyst were applied to develop benzothiazole derivatives in recent years. ${ }^{20}$ However, most procedures have some of disadvantages that are hazardous, carcinogenic solvents like chloroform, ${ }^{21}$ DMSO, ${ }^{22}$ $\mathrm{MeCN},{ }^{23}$ dioxane ${ }^{24}$ were applied, expensive and toxic catalyst ${ }^{25}$ were used, recyclability of the catalyst was noticeable in a few papers ${ }^{26}$ and in most papers multistep reaction and complex purification technique were accomodated ${ }^{27}$.

So it is very important to switchover above difficulties and come up with new simple, eco-friendly and efficient methods to develop 2-substituted benzothiazole and benzothiazoline derivatives with green catalyst. In recent study PFPAT $\left(\mathrm{C}_{6} \mathrm{~F}_{5} \mathrm{NH}_{3} \mathrm{OTf}\right.$;) worked well as a novel organocatalyst in the conversion of esterification of carboxylic acid and enol silyl ether formation. ${ }^{28}$ However, still now there is no application of this novel organocatalyst as a Brønsted acid in aqueous medium to develop these derivatives. Here I report the synthesis of benzothiazole and also benzothiazoline derivatives using PFPAT catalyst through a condensation method in water.

\section{EXPERIMENTAL}

Chemicals were purchased from SRL India and Spectrochem Pvt. Ltd. ${ }^{1} \mathrm{H}$ and ${ }^{13} \mathrm{C}$ NMR spectra were recorded on a Bruker $300 \mathrm{MHz}$ instrument. From Aldrich chemical company NMR solvents $\mathrm{CDCl}_{3}$, DMSO- $d_{6}$ and TMS as the internal standard were purchased. Electrical melting point apparatus were used to determine the melting point. Perkin Elmer Spectrophotometer was used to study FT-IR spectra. Thin layer chromatography was used to monitor the reaction. For recrystallisation, aqueous ethanol was used as solvent.

\section{Preparation of the PFPAT catalyst}

In toluene $25 \mathrm{mmol}$ pentafluoroaniline and $25 \mathrm{mmol}$ trifluoromethane sulphonic acid were added and stirred for $30 \mathrm{~min}$ at $0-5^{\circ} \mathrm{C}$ temperature. The solvent was evaporated after completion of the reaction under vaccum. Then crude product was collected and washed with hexane to produce the pure catalyst. ${ }^{31 \mathrm{c}}$

\section{General Procedure}

In a round-bottomed flask substituted benzaldehyde (1 mmol, 2) and ortho-aminothiophenol $(1.2 \mathrm{mmol}, 1)$ were mixed and dissolved in $10 \mathrm{~mL}$ water. Then PFPAT $(0.2 \mathrm{mmol})$ catalyst was added. It was stirred in oil bath at $60^{\circ} \mathrm{C}$ for the appropriate time. The reaction was monitored by silica coated thin layer chromatography plate in presence of $\mathrm{MeCO}_{2} \mathrm{Et}$ and petroleum ether solvent. The reaction completed within 4.5-6 $\mathrm{h}$ confirmed by the developing brown spot in iodine chamber. Then the crude product was cooled and filtered. Crude product was washed with minimum volume of mixture of ethylacetate and petroleum ether. Finally the washed product was cryatallized directly from hot aqueous ethanol (80\%). The filtrate containing PFPAT was regenerated and directly used by adding it into the reactants. Character analysis of the product (3a-o) and (4a-c) were compared by FT-IR, ${ }^{1} \mathrm{H}$ NMR and ${ }^{13} \mathrm{C}$ NMR data with authentic known compounds.

\section{Selected characterization data for synthesized compounds 2-(2'-Chlorophenyl)-benzothiazole (Entry 8, Table 3)}

White color solid, FT-IR $\left(\mathrm{KBr}, \mathrm{cm}^{-1}\right)$ : 3435, 
2363, 1423, 1266, 1053 and 755, ${ }^{1} \mathrm{H}$ NMR $(300 \mathrm{MHz}$, $\left.\mathrm{CDCl}_{3}\right)$ 8: 8.21-8.18 (m, 1H), $8.12(\mathrm{dd}, 1 \mathrm{H}), 7.94$ (dd, $1 \mathrm{H})$, 7.54-7.49 (m, 2H), 7.44-7.38 (m, 3H) ${ }^{13} \mathrm{C}$ $\operatorname{NMR}\left(75 \mathrm{MHz}, \mathrm{CDCl}_{3}\right)$ : $164.2,152.5,136.1,132.7$, 132.3, 131.7, 131.1, 130.8, 127.1, 126.3, 125.4, 123.5, 121.4. Analytical calculation for $\mathrm{C}_{13} \mathrm{H}_{8} \mathrm{CINS}$ (\%): C: 63.54; H: 3.28; N: 5.70, Found: C: 63.41; H: 3.12; N: 5.59 .

\section{2-(2'-Hydroxyphenyl)-benzothiazole (Entry 2, Table 5)}

White color solid, IR $\left(\mathrm{KBr}, \mathrm{cm}^{-1}\right)$ : 3437 , 2923, 2372, 1580, 1477, 1210 and $742,{ }^{1} \mathrm{H}$ NMR $\left(300 \mathrm{MHz}, \mathrm{CDCl}_{3}\right.$ ) 8: 12.52 (brs, $1 \mathrm{H}$ ), 8.00 (brd, $1 \mathrm{H}), 7.91(\mathrm{brd}, 1 \mathrm{H}), 7.71(\mathrm{dd}, 1 \mathrm{H}), 7.51(\mathrm{dt}, 1 \mathrm{H})$, $7.40(\mathrm{dt}, 2 \mathrm{H}), 7.11(\mathrm{dd}, 1 \mathrm{H}), 6.97(\mathrm{dt}, 1 \mathrm{H}),{ }^{13} \mathrm{C}$ NMR $\left(75 \mathrm{MHz}, \mathrm{CDCl}_{3}\right) \delta: 169.4,158.0,151.9$, 132.8, 132.6, 128.4, 126.7, 125.6, 122.2, 121.5, $119.5,117.9,116.8$. Analytical calculation for $\mathrm{C}_{13} \mathrm{H}_{9} \mathrm{NOS}(\%)$ : C: $68.70 ; \mathrm{H}: 3.99$; N: 6.16; Found: C: $68.59 ; \mathrm{H}: 3.82 ; \mathrm{N}: 6.04$.

\section{2-(2'-Chlorophenyl)-benzothiazoline (Entry 1, Table 4)}

White color solid, FT-IR $\left(\mathrm{KBr}, \mathrm{cm}^{-1}\right): 3344$ 3063, 2371, 1573, 1462, 1240, 1033 and 734, ${ }^{1} \mathrm{H}$ NMR $\left(300 \mathrm{MHz}, \mathrm{CDCl}_{3}\right)$ : : 7.77-7.71 (m, 1H), 7.40$7.31(\mathrm{~m}, 1 \mathrm{H}), 7.28-7.18(\mathrm{~m}, 2 \mathrm{H}), 7.04(\mathrm{dd}, 1 \mathrm{H}), 6.95$ (dt, $1 \mathrm{H}), 6.79-6.71(\mathrm{~m}, 2 \mathrm{H}), 6.66\left(\mathrm{~s}, 1 \mathrm{H}, \mathrm{C}_{2}\right.$ proton), 4.43 (brs, $1 \mathrm{H}, \mathrm{N}-\mathrm{H}),{ }^{13} \mathrm{C}$ NMR $\left(75 \mathrm{MHz}, \mathrm{CDCl}_{3}\right.$ ) $\delta$ : 146.1, 140.0, 131.6, 129.6, 129.3, 127.4, 127.3, $126.3,125.5,122.0,121.1,110.4,65.6$. Analytical calculation for $\mathrm{C}_{13} \mathrm{H}_{10} \mathrm{CINS}(\%)$ : C: $63.02 ; \mathrm{H}: 4.07 ; \mathrm{N}$ : 5.65; Found: C: 62.92; H: 3.95; N: 5.51.

\section{RESULTS AND DISCUSSIONS}

To find out the optimization condition of the benzothiazole formation, first the reaction was carried out between 2-aminothiophenol $(1 \mathrm{mmol})$ and 4-chlorobenzaldehyde $(1 \mathrm{mmol})$ as model substrates under different conditions to investigate the influence of catalyst in aqueous medium.

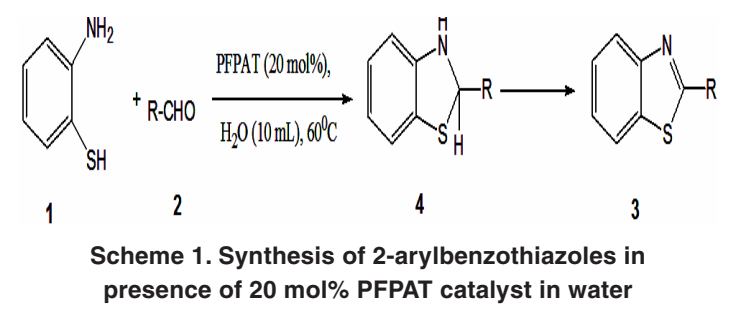

The reaction mixture was heated with different amount of the PFPAT catalyst in water at variable temperature and the result were summarized in Table 1. It was noticeable that the initiation of the reaction depends on the amount of catalyst PFPAT and also temperature. The reaction was very slow without catalyst at $60^{\circ} \mathrm{C}$ and same situation repeated when catalyst $(20 \mathrm{~mol} \%$ ) was used at room temperature but both reactions were continued for 8 h separately. (Entries 1and 2, Table 1).

Table 1: Study of optimization of the reaction for the formation of 2-(4'-chlorophenyl)-benzothiazole (3f) in different mol\% of catalyst PFPAT (Entry 6, Table 3)

\begin{tabular}{ccccc}
\hline Entry & $\begin{array}{c}\text { PFPAT } \\
(\mathrm{mol} \%)\end{array}$ & Conditions & $\begin{array}{c}\text { Time } \\
(\mathrm{h})\end{array}$ & $\begin{array}{c}\text { aYield } \\
(\%)\end{array}$ \\
\hline 1. & 0 & Oil bath $60^{\circ} \mathrm{C}, \mathrm{H}_{2} \mathrm{O}$ & 8 & 20 \\
2. & 20 & Room temp, $\mathrm{H}_{2} \mathrm{O}$ & 8 & 30 \\
3. & 05 & Oil bath $60^{\circ} \mathrm{C}, \mathrm{H}_{2} \mathrm{O}$ & 10 & 40 \\
4. & 10 & Oil bath $60^{\circ} \mathrm{C}, \mathrm{H}_{2} \mathrm{O}$ & 8 & 48 \\
5. & 15 & Oil bath $60^{\circ} \mathrm{C}, \mathrm{H}_{2} \mathrm{O}$ & 7.5 & 56 \\
6. & 15 & Oil bath $80^{\circ} \mathrm{C}, \mathrm{H}_{2} \mathrm{O}$ & 7 & 62 \\
7. & 20 & Oil bath $50^{\circ} \mathrm{C}, \mathrm{H}_{2} \mathrm{O}$ & 8 & 70 \\
8. & 20 & Oil bath $60^{\circ} \mathrm{C}, \mathrm{H}_{2} \mathrm{O}$ & 5.5 & 90 \\
9. & 20 & Oil bath $80^{\circ} \mathrm{C}, \mathrm{H}_{2} \mathrm{O}$ & 5.5 & 89 \\
10. & 25 & Oil bath $50^{\circ} \mathrm{C}, \mathrm{solvent}$ free & 8 & 52 \\
11. & 25 & Oil bath $60^{\circ} \mathrm{C}, \mathrm{H}_{2} \mathrm{O}$ & 5.0 & 90 \\
12. & 25 & Oil bath $80^{\circ} \mathrm{C}, \mathrm{H}_{2} \mathrm{O}$ & 5.0 & 91 \\
alsolated Yield & &
\end{tabular}

It was noticeable that in this model reaction the gradual increase of the mol\% of PFPAT at $60^{\circ} \mathrm{C}$ temperature, the overall yield of the reaction gradually increases. Investigating reaction completed within $5.5 \mathrm{~h}$ and maximum yield $90 \%$ was isolated (Entry 8 , Table 1). Below temperature $60^{\circ} \mathrm{C}$ very low yields was seen but above $60^{\circ} \mathrm{C}$ no improved yield was observed (Entries 9 and 12, Table 1). Low yields may be attributed due to benzothiazoline generation along with benzothiazole and also present of unreacted aldehyde in the reaction medium. (Entry 7 , Table 1).

Table 2: Solvent effect for the formation of compound 2-(4'-chlorophenyl)-benzothiazole (3f) (Entry 6, Table 3)

\begin{tabular}{ccccc}
\hline Entry & $\begin{array}{c}\text { Solvent } \\
(10 \mathrm{~mL})\end{array}$ & aConditions & $\begin{array}{c}\text { Time } \\
(\mathrm{h})\end{array}$ & $\begin{array}{c}\text { bYield } \\
(\%)\end{array}$ \\
\hline 1. & Toluene & Oil bath, $60^{\circ} \mathrm{C}$ & 8 & 32 \\
2. & $\mathrm{THF}$ & Oil bath, $60^{\circ} \mathrm{C}$ & 8 & 40 \\
3. & $\mathrm{MeCN}$ & Oil bath, $60^{\circ} \mathrm{C}$ & 8 & 42 \\
4. & $\mathrm{EtOH}$ & Oil bath, $60^{\circ} \mathrm{C}$ & 8 & 50 \\
5. & $\mathrm{AqEtOH}(1: 1)$ & Oil bath, $60^{\circ} \mathrm{C}$ & 5.5 & 60 \\
6. & $\mathrm{H} \mathrm{O}$ & Oil bath, $60^{\circ} \mathrm{C}$ & 5.5 & 90 \\
7. & $\mathrm{NIL}$ & Oil bath, $60^{\circ} \mathrm{C}$ & 8 & 30 \\
\hline
\end{tabular}

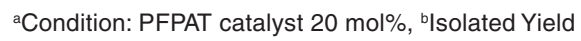


Solvent effect has been studied to finalize the optimization condition in this reaction. So to investigate the various solvent effects the reaction was carried out between 2-aminothiophenol and 4-chlorobenzaldehyde in presence of $20 \mathrm{~mol} \%$ of PFPAT catalyst at $60^{\circ} \mathrm{C}$. Examination reveals that the highest yield of the product in the reaction was observed in water medium (Entry 6, Table 2) and even in aqueous alcoholic medium (1:1), moderate yield was obtained (Entry 5, Table 2). Finally conclusion has been made that $20 \mathrm{~mol} \%$ of Bronsted acid catalyst PFPAT worked well at $60^{\circ} \mathrm{C}$ temperature in aqueous medium to synthesize the excellent product (3) yields.

After the evaluation of the generality of the model reaction then various 2 -substituted benzothiazole derivatives were synthesized under the optimized reaction condition. Here both electron donating and withdrawing groups were involved but no distinct difference in the percentage yield was observed in the product that means all the substrates reacted uniformly with 2-aminothiophenol under this reaction condition. Rate of the reaction depends on the substitutent nature of the aldehyde although all reactions completed within 6 hours. Here $m$-nitro, $p$-chloro, $o$-nitro and o-methoxy benzaldehyde (Entries 1, 6, 7 and 11, Table 3) gave good yield at comparatively short reaction time on the other hand $p$-methoxy, $p$-hydroxy, $p$-N, N-dimethylamino benzaldehyde gave slight lower yield even after $6 \mathrm{~h}$ of the reaction. It may be attributed because of lower electrophilic nature of aldehydes group present in substituted benzaldehyde. For heteroaromatic aldehydes this methods works equally well and the results are represented in entry 10, Table 3.

It was noted that benzothiazoline was generated under this reaction condition when reaction took place between o-hydroxybenzaldehyde and $o$-aminothiophenol and the stability of the benzothiazoline may be attributed by intramolecular hydrogen bonding which prevents the aerial oxidation to generate benzothiazole derivatives. Since reaction between o-hydroxybenzaldehyde and $o$-aminothiophenol stops at the benzothiazoline stage so conversion of benzothiazole of o-hydroxybenzaldehyde was carried out at high temperature under the same reaction condition (Scheme 3).

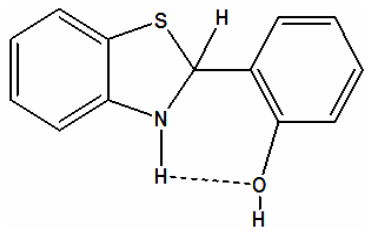

Fig. 1. Intramolecular hydrogen bonding stability of the 2-hydroxy benzothiazoline derivative

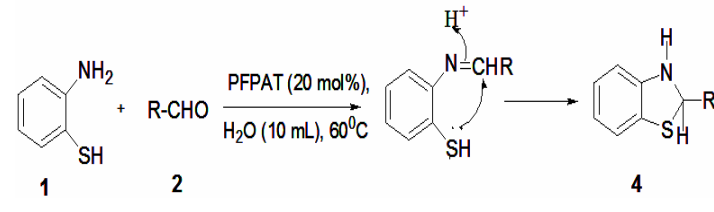

Scheme 2. Synthesis of benzothiazoline in presence of $20 \mathrm{~mol} \%$ PFPAT catalyst at $60^{\circ} \mathrm{C}$ in water

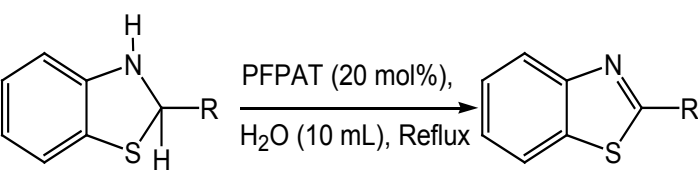

Scheme 3. Conversion of 2-substitutedbenzothiazolines to 2-substitutedbenzothiazoles

From the above discussion author conclude that the 2-substituted benzothiazole no $\mathrm{N}-\mathrm{H}$ peak at 4-4.5ppm and no $\mathrm{C}_{2}-\mathrm{H}$ peak at approximately 6.33-6.70 ppm in ${ }^{1} \mathrm{HNMR}$ spectra was obtained from oxidation of benzothiazoline intermediate because isolation was done of the benzothiazoline derivatives from the following aldehydes like 2-chloro, 2-hydroxy and 4-nitrobenzaldehydes. It was achieved when the reaction was continued for a shorter time period (Table 4). $\delta$ value at $4.43 p p m$ brs and $6.66 p p m$ singlet in proton NMR spectra indicates $\mathrm{N}-\mathrm{H}$ proton and $\mathrm{C}_{2}-\mathrm{H}$ present respectively in 2-(2'-Chlorophenyl)benzothiazoline compound (4a) (Entry 1, Table 4). Author has done one experiment in anaerobic condition (absence of oxygen) only benzothiazoline was isolated and benzothiazole never obtained although the reaction was continued for longer time under this reaction condition. So oxygen was essential for oxidation from benzothiazoline to benzothiazole.

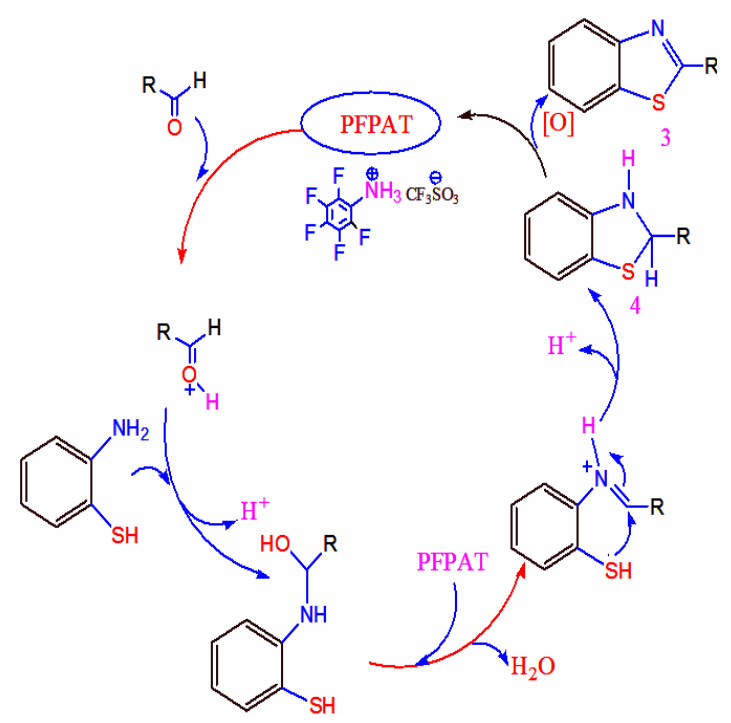

Scheme 4. General mechanism for the formation of benzothiazole derivative 
Table 3: Synthesis of 2-substituted benzothiazoles catalysed by PFPAT

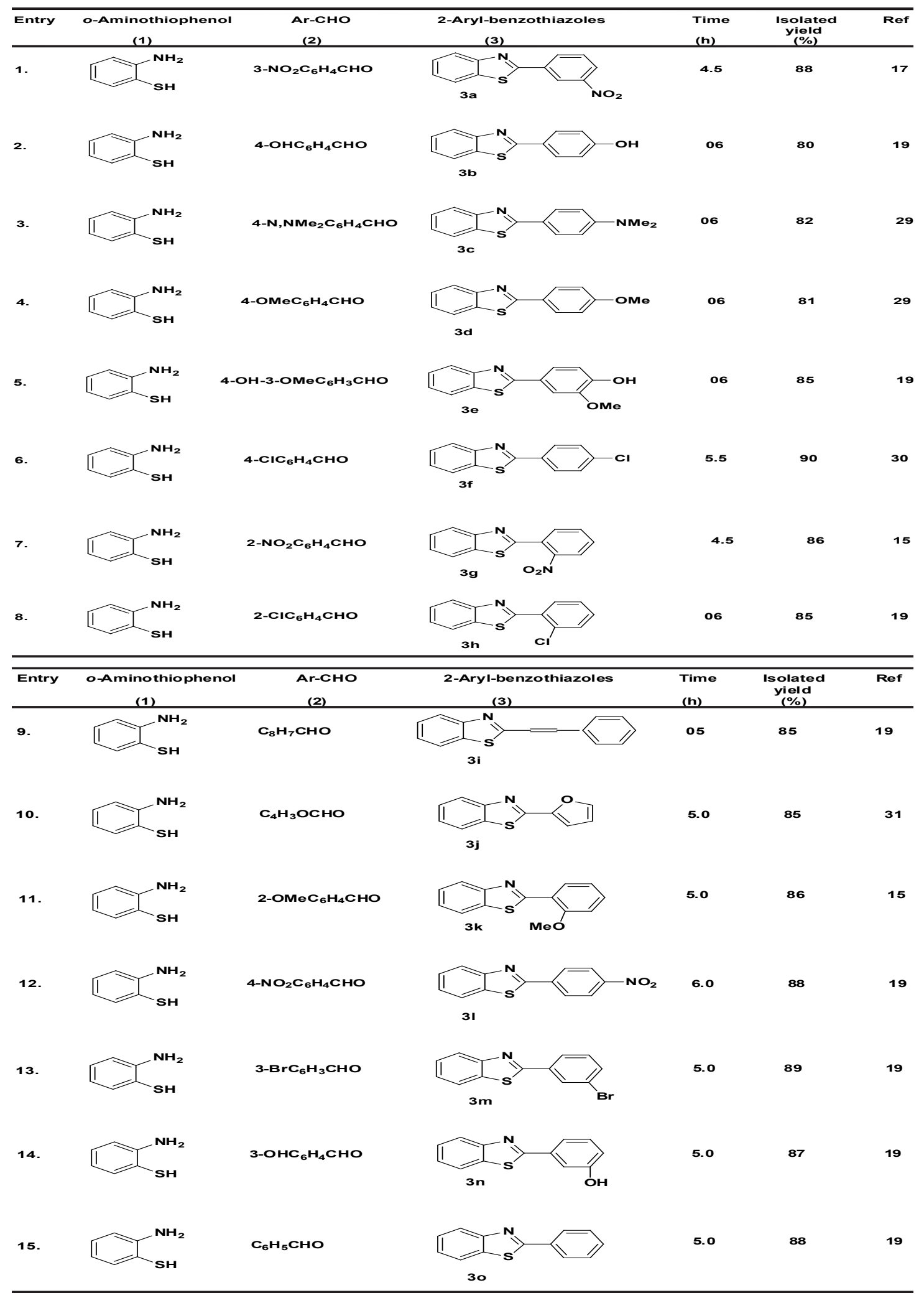


The plausible mechanistic pathway is depicted in Scheme 4 to generate 2-arylbenzothiazole derivatives using o-aminothiophenol and substituted aldehydes. Since PFPAT acts as a Bronsted acid in aqueous medium so in the first step protonation takes place at the carbonyl oxygen centre which makes more electrophilicity of the carbonyl carbon. Intermediate 4 was obtained by the reaction with o-aminothiophenol and then benzothiazole derivative 3 was generated by oxidation of intermediate 4 and details mechanism shown in Scheme 4.

Table 4: Synthesis of 2-arylbenzothiazolines

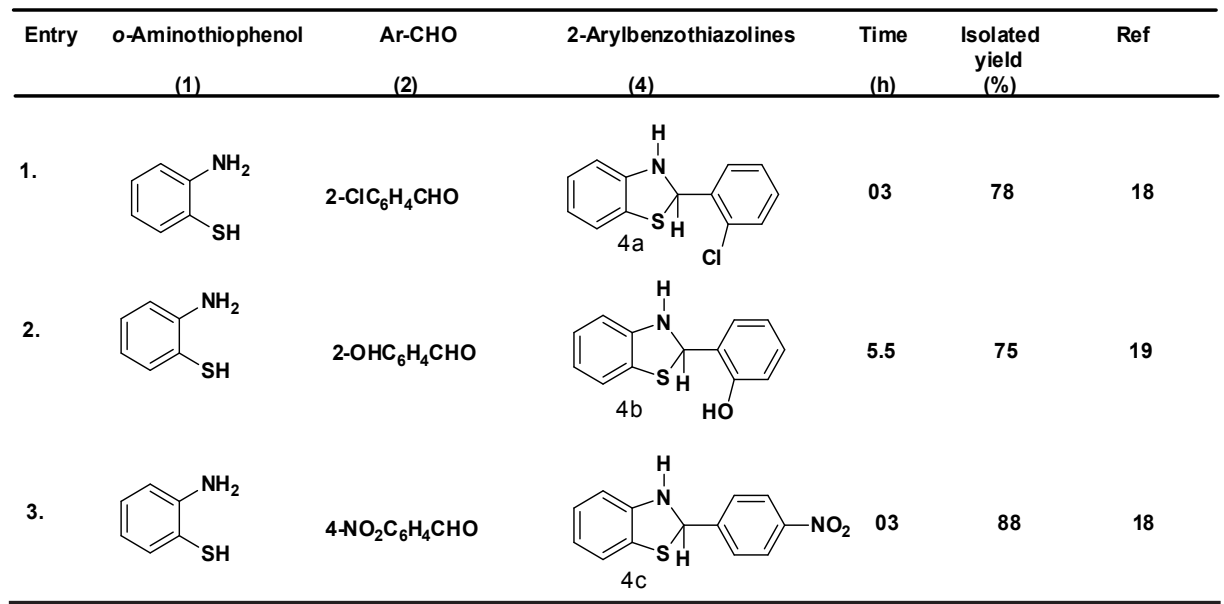

Recycling of catalyst is very important in organic reactions and as well as in commercial purpose. So recycle activity studied of PFPAT catalyst in this reaction. The catalyst is soluble in water and it was recovered by evaporation of the filtrate. Then it was washed with hexane and dried under vacuum. PFPAT catalyst was reused in the next four consecutive reactions maintaining the same reaction conditions. Investigation reveals that there were no major loss of its efficacy of catalyst even after using four times in the reaction and it is clearly represented in graphical method Fig. 2 . The following advantages of this work were observed in contrast with other reported procedures such as (a) environmentally benign reaction and cheap reaction procedure (b) pentafluoroaniline and triflic acid were used to prepare PFPAT very easily ${ }^{31 c}$ (c) isolation and purification of the product was very simple (d) catalyst was used four times without loss of its efficacy (e) solid crude compound was crystallized from hot aqueous ethanol directly after separation of catalyst by simple filtration from aqueous medium (f) no need of column chromatography for purification step and $(\mathrm{g})$ this protocol may be used to prepare benzothiazole derivatives in large scales in near future.

Table 5: Synthesis of 2-substitutedbenzothiazolines to 2-substitutedbenzothiazoles

Entry 2-Arylbenzothiazoline




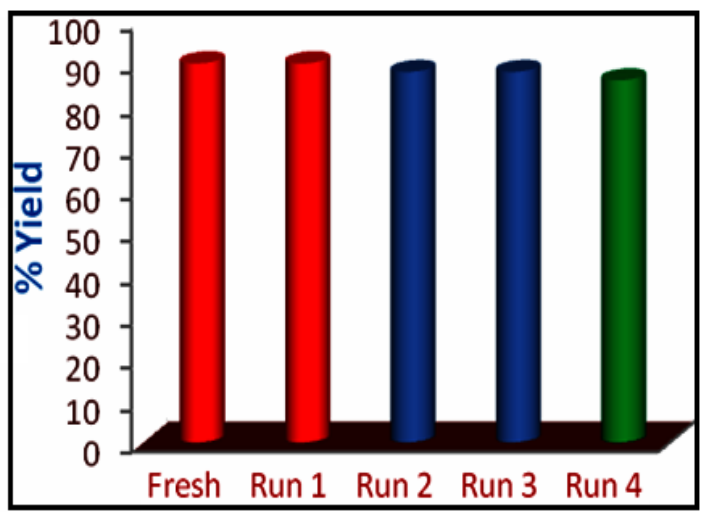

Fig. 2. Graphical representation of yields of the reaction carried out by using reused catalyst PFPAT for the formation of 2-(4'-Chlorophenyl)-benzothiazole (Table 3, 3f)

\section{CONCLUSION}

In this reaction a simple, mild and eco-friendly reaction is reported in presence of an effective, inexpensive and recyclable organocatalyst for the synthesis of benzothiazole and benzothiazoline derivatives in excellent and moderate yield respectively. In addition this protocol has a tolerance in case of various electron donating and withdrawing substituents which gave high yield of benzothiazole and moderate yield of benzothiazoline. Details mechanism is narrated in this work. It is hoped that in near future this procedure will be useful in terms of academically and industrially.

\section{ACKNOWLEDGEMENT}

Author is very much grateful to his $\mathrm{PhD}$ supervisor Professor Chhanda Mukhopadhyay, Department of Chemistry, University of Calcutta for providing him laboratory facility and financial support.

\section{Conflict of Interest}

No conflict of interest regarding this article.

\section{REFERENCES}

1. Rideout, D.C.; Breslow, R.; J. Am. Chem. 1980, 102, 7816-7817.

2. Breslow, R.; Acc. Chem. Res., 1991, 24, 159164.

3. (a) Arienti, K. L.; Brunmark, A.; Axe, F. U.; McClure, K.; Lee, A.; Blevitt, J.; Neff, D. K.; Huang, L.; Crawford, S.; Pandit, C. R.; Karlsson, L.; Breitenbucher, J. G.; J. Med. Chem., 2005, 48, 1873-1885. (b) Sann, L. A.; Baron, J.; Mann, H.; vanden, B.; Gunaratnam, M.; Neidle, S.; Org. Biomol. Chem., 2006, 4, 1305-1312.

4. (a) Roche, S. P.; Teyssot, M. L.; Gautier, A.; Tetrahedron Lett., 2010, 51, 1265-1268. (b) Herrmann, W. A.; Kohlpaintner, C.W.; Angew. Chem. Int. Ed. Engl., 1993, 32, 1524. (c) Lindstrom, U. M.; Chem. Rev., 2002, 102, 2751-2772. (d) Kobayashi, S.; Manabe, K.; Acc. Chem. Res., 2002, 35, 209-217.

5. (a) Bradshaw, T. D.; Westwell, A. D.; Curr. Med. Chem., 2004, 11, 1009-1021. (b) Hays, S.; Rice, J. M. J.; Ortwine, D. F.; Johnson, G.; Schwaez, R. D.; Boyd, D. K.; Copeland, L. F.; Vartanian, M. G.; Boxer, P. A.; J. Pharm. Sci., 1994, 83, 1425-1432. (c) Paget, C. J.; Kisner, K.; Stone, R. L.; Delong, D. C.; J. Med. Chem., 1969, 12, 1016 -1018. (d) Kumar, D.; Jacob, M. R.; Reynolds, M. B.; Kerwin, S. M.; Bioorg.
Med. Chem., 2002, 10, 3997-4004.

6. (a) Mathis, C. A.; Wang, Y.; Holt, D. P.; Huang, G. F.; Debnath, M. L.; Klunk, W. E.; J. Med. Chem., 2003, 46, 2740-2755. (b) Hutchiuson, I.; Jennings, S. A.; Vishnuvajjala, B. R.; Westwell, A. D.; Stevens, M. F. G.; J. Med. Chem., 2002, 45, 744-747. (c) Alagille, D.; Baldewin, R. M.; Tamagnan, G. D.; Tetrahedron Lett., 2005, 46, 1349-1351. (d) Canjolle, R.; Loiseau, P.; Payard, M.; Gayral, P.; Ann. Pharm. Fr., 1989, 47, 6873. (e) Yamamoto, K.; Fujita, M.; Tabashi, K.; Kawashima, Y.; Kato, E.; Oya, M.; Iso, T.; Lwso, J.; J. Med. Chem., 1988, 31, 919930. (f) Yoshida, H.; Nakao, R.; Nohta, H.; Yamaguchi, M.; Dyes Pigm., 2000, 47, 39245. (g) Petkov, I.; Deligeorgiev, T.; Markov, P.; Evstatiev, M.; Fakirov, S.; Polym. Degrad. Stab., 1991, 33, 53-66.

7. Sharghi, H.; Omid, A.; Synth. Commun., 2009, 39, 860-867.

8. Nadaf, R. N.; Siddiqui, S. A.; Daniel, T.; Lahoti, R. J.; Srinivasan, K. V.; J. Mol. Catal. A: Chem., 2004, 214, 155-160.

9. Matsushita, H.; Lee, S. H.; Joung, M.; Clapham, B.; Janda, K. D.; Tetrahedron Lett., 2004, 45, 313-316. 
10. Tale, R. H.; Org. Lett., 2002, 4, 1641-1642.

11. Al-Qalaf, F.; Mekheimer, R. R.; Sadek, K. U.; Molecules., 2008, 13, 2908-2914.

12. Ranu, B. C.; Jana, R.; Dey, S.; Chem. Lett., 2004, 33, 274-275.

13. Bougrin, K.; Loupy, A.; Soufiaoui, M.; Tetrahedron., 1998, 45, 8055-8064.

14. Itoh, T.; Nagata, K.; Ishikawa, H.; Ohsawa, A.; Heterocycles., 2004, 62, 197-201.

15. Aliyan, A.; Fazlaeli, R.; Fazaeli, N.; Mssah, A. R.; Javaherian-Naghash, H.; Alizadeh, M.; Emami G.; Heteroatom Chem., 2009, 4, 202-207.

16. Patel, N. B.; Shaikh, F. M.; Sci Pharm., 2010, 78, 753-765.

17. Pratap, U. R., Mali, J. R., Jawale, D.V.; Mane, R. A.; Tetrahedron lett., 2009, 50, 1352-1354.

18. Makhopadhyay, C.; Datta, A.; J. Het.Chem., 2009, 46, 91-95.

19. Makhopadhyay, C.; Datta, A, Heterocycles., 2007, 71, 1837-1842.

20. (a) Kazi, I.; Sekar, G.; Org. Biomol. Chem., 2019, 17, 9743-9756. (b) Merroun, Y.; Chehab, S.; Ghailane, T.; Akhazzane, M.; Souizi1, A.; Ghailane, R.; Reac Kine. Mech Cat., 2019, 126, 249-264. (c) Bhat, R.; Karhale, S.; Arde, S.; Helavi, V.; Iran. J. Catal., 2019, 9, 173-179. (d) Bouchet, L. M.; Heredia, A. A.; Arguello, J. E.; Schmidit, L. C.; Org. Lett., 2019, 22, 610-614.

21. (a) Umesh, R. P.; Jyotirling, R.M.; Dhanaji, V. J.; Ramrao, A. M.; J. Tetrahedron Lett., 2009, 50, 1352-1354.(b) Jun, M. X.; Ping, Z.
J.; Sheng, Z. R.; JunChen, W.; Tetrahedron Lett., 2005, 46, 4345-4347. (c) Xu, Z. M.; Li, H. X.; Young, D. J.; Zhu, D. L.; Li, H. Y.; Lang, J. P.; Org. Lett., 2019, 21, 237-241.

22. Hu, R.; Li, X.; Tong, Y.; Miao, D.; Pan, Q.; Jiang, Z.; Gan, H.; Han, S.; Synlett., 2016, 27, 13871390. (b) Dey, A.; Hajra, A.; Org. Lett., 2019, 21, 1686-1689.

23. Babu, K. R.; Zhu, N.; Bao, H.; Org. Lett., 2017, 19, 46-49.

24. Yu, H.; Zhang, M.; Li, Y.; J. Org. Chem., 2013, 78, 8898-8899.

25. Huang, J.; Chan, J.; Chen, Y.; Borths, C. J.; Baucom, K. D.; Larsen, R. D.; Faul, M. M.; J. Am. Chem. Soc., 2010, 132, 3674-3675.

26. Mali, J. R.; Jawale, D. V.; Londhe, B. S.; Mane, R. A.; Green Chem. Lett. Rev., 2010, 3, 209-212.

27. Khokra, S. L.; Kanika, A.; Heena, M.; Ajay, A.; Manish, Y.; International Journal of Pharm Sci and Res., 2011, 2, 1356-1377.

28. lida, A.; J. and R. Nagase, Org. Lett., 2007, 9, 1859-1862.

29. Sadek, K.; Mekheimer, R.; Hameed, A. A.; Elnahas, F.; Elnagdi, M. H.; Molecules., 2012, 17, 6011-6019.

30. Maleki, B.; Salehabad, H.; Eur. J. Chem., 2010, 4, 377-380.

31. (a) Mali, J. R.; Jawale, D. V.; Londhe, B. S.; Mane, R. A.; Green Chem Lett Rev., 2010, 3, 209-212. (b) Khaksar, S.; Radpeyma, H.; C.R. Chimie., 2014, 17, 1023-1027. (c) Funatomi T, Wakasugi K, Misaki T, Tanabe Y. Green Chem., 2006, 8, 1022-1027. 